\title{
Characteristics' Analysis of Urban System in Northern Upper Egypt Region (NUE) Size Distribution Analysis of Urban Settlements; 1976 2016
}

\author{
Ashraf Abo Loyoun Abdel Raheam, Usama Helmy Mohamed, Amany Nagy Abd Elhafez, Asmaa Ahmed Osman* \\ Department of Architecture, Faculty of Engineering, Minia University, 61519 Minia, Egypt \\ * Correspondence: asmaa.osman@mu.edu.eg; Tel: +201201909951; Fax: +20 86236674
}

\section{Article information}

Received: 26 January 2020

Revised: 3 March 2020

Accepted: 4 March 2020

\section{Key words}

Urban system

Size distribution

Primate city

Rank and size

Urban Primacy

Northern Upper Egypt region (NUE)

GIS programme

\begin{abstract}
Characteristics of urban system of regional structure are: size of settlements, their spatial distribution, and their functions. Despite rapid development in Egypt, suffecient studies of the development patterns of its territories have not been sufficiently achieved or covered. Like other regions of the Nile valley in Egypt, Northern Upper Egypt region (NUE) was characterized by its natural, social, and economic homogeneity for long periods of time. But the accelerated development that has given rise to new axes of movement has revealed imbalances in a pattern that has not been analitacally studied to help guide current and future development processes. Thus, this research focuses on analyzing size distribution (as the most important element of the structure). The aim of this paper, therefore, is to analyse the size distribution of urban system in the northern oblasts in terms of: the change in the size, proportions and growth rates of urban agglomerations over the past 40 years, the change in their grade and size distribution, followed by a change in their urban dominance. To achieve this, the paper reviews a theoretical review of methods for analysing urban styles/systems size distribution. The paper then examines an analysis of the size distribution of northern regions using some theoretical and applied measures (Primate City law, Size-Rank Distribution, Urban Primacy Index). The research concludes a set of findings and recommendations that may help to understand the size distribution of the northern region as one of its most important characteristics. Search also used GIS programme ((Arc GIS Desktop) to analyse spatial relationships between groups of different size strips to ensure accuracy of results.
\end{abstract}

\section{Introduction}

There are many literary readings on the concept of urban system" [2], [3], [4], [5], [6], [7], [8], from which we deduce the concept of urban system as a group of urban and rural settlement dispersed by size within a hierarchy of small and large urban settlement. It has a dominant urban primacy - the city of the province - and is spread spatially within a specific system that varies from environment to environment depending on natural, social and economic conditions. They are connected by a series of regional links of roads, railways, land areas, and these communities interact with each other - urban and rural - as well as with surrounding areas within the region, These interactions are the key determinants of the network of urban system [9].

Northern Upper Egypt region is a testament to the development of human civilization from prehistoric times through Pharaonic, Greek, and Roman civilizations to Coptic and Islamic times. Because of its unique location, the province has many traces of natural and environmental suitability for human settlement in different historical times [10]. Human settlements in the Nile valley have grown over time under very similar social, economic and technological conditions, with the Nile river as the most important natural feature and agriculture as the main economic activity. However, the Nile valley has undergone dramatic and accelerated economic, social and demographic changes over the past 200 years, very different from the Nile valley's stability and tranquillity over the previous 5,000 years. With the real impact of the industrial revolution in Egypt in the mid-nineteenth century, and nearly a hundred years after it in Europe, economic and social conditions in the region began to change. This has been achieved through a series of major projects in the areas of roads, transport, agriculture, irrigation, industry and urbanization [11]. The main developments in the Northern upper region (the study area) in the past 30 years have been the emergence of the eastern desert road, the western route, and the Karimat road, These roads have contributed to the emergence of large development landscapes and land reclamation areas, new industrial zones, infrastructure projects and many new settlement developments (new towns and villages of agrarian reclamation). All these dramatic and accelerating changes in the region are expected to have a significant impact on its urban system characteristics. However, the current effects and characteristics of this system have not yet been precisely identified, This makes it necessary to identify the characteristics of the existing urban system of the territory, so 
that future development projects can be planned in accordance with or integrated with the existing urban system.

The rearch used GIS software (ArcCatalog) \& (ArcMap) to analyse spatial relationships between groups of different sizes to ensure accuracy of results.

\section{Aim of the research}

The aim of this paper is to analyse the size distribution of urban system in the Northern Upper Egypt region in an attempt to identify one of the main features of the urban system in its region. By studying the change in population ratios and growth rates in different sizes of these populations, rank and size analysis, urban primacy, and has changed over a long period of time (1976 to 2016), its contours and implications.

\section{Research methodology}

The research begins with a theoretical review of methods for analysing the size distribution of urban settlements in general, followed by applied study in Northern Upper Egypt region by statistical analysis of the size distribution characteristics of urban settlements. The research covers a geographical area in the northern region of upper Egypt including the governorates of Minya and Beni Suef; excluding the governorate of Fayoum for the following reasons:

- Natural, social, and economic characteristics of Fayum governorate differ from the rest of the region and are characterized by oasis characteristics.

- The pattern and form of distribution of urban settlement in Fayoum governorate differ from that of the northern part of the country. The distribution of settlements depends on the diffuse pattern (similar to that of the Nile delta as it relates to the expansion of the delta's agricultural area), unlike the axis pattern in the provinces of Minya and Beni Suef, which stretches along the valley on the Nile banks.

- The 2006 regional difference coefficient ${ }^{\left[{ }^{* 1]}\right.}$ for the region as a whole (Minya, Beni Suef and Fayoum provinces) was $10.56 \%$. If limited to Beni Suef and Minya only, this coefficient is only $1.76 \%$, indicating that the territory would be more homogeneous with Fayoum governorate [12].

Thus, Fayoum governorate was excluded, because if it is incorporated into the study of the region with these differences in place, this would lead to unrealistic and potentially misleading results.

With regard to the size classification of urban settlement in the Nile valley; the research has adopted the classifications presented in two studies. First: the general authority for urban planning prepared "study on urban development strategy for the north upper Egypt region" In 2004 [13]. Urban settlement -cities only- in the north of upper level were classified into five size categories: less than 20,000,50,000, 100,000, 250,000, and more than 250,000 of populations.

The second study was dissertation by researcher Mahmoud Fouad El Buwab, "spatial distribution patterns of urban settlement - an analytical study of the Egyptian urban system", in 2004, [14] which classified Egypt's settlements into four size categories of cities and four other categories of villages. The categories of cities included: less than 40,000, 40-100,000, 100-500,000, and more than a million of populations. The village categories included small villages (less than 10,000), medium villages $(10,000-20,000)$, large villages $(20,000-50,000)$, and giant villages (more than 50,000 of populations).

With the exclusion of Fayoum governorate, the study of urban planning authority could also be taken into account in the classification of rural settlement by Dr. Mahmoud Fouad ElBuwab. This is in seven categories as follows: First, five categories of urban settlement including groups of less than 20,$000 ; \quad 20,000-50,000 ; \quad 50,000-100,000 ; \quad 100,000-250,000$; 250,000 -million of populations. Second, two categories of rural settlement, including groups of 20,000-50,000; and larger than 50,000 of populations. The research is considering only the main big villages; because they are the most populous, functional, and therefore the most influential in terms of the existing urban system of the region compared to other villages. It is difficult to cover all the villages because of the size of the area and the dispersion of the villages.

The rearch used GIS software (ArcCatalog) \& (ArcMap) to analyze spatial relationships between groups of different sizes, to ensure accuracy of results. Questions based on population characteristics by size have been used (Select by attribute) in (ArcMap). Also, data computation tools based on other data were used (Filed Calculator), to automatically calculate the ratios of urban and rural settlement in the study area, the ratios of its population by size categories, the actual proportions of settlement size, the theoretical proportions according to the law of the first city, according to the law of ranksize, and the index of urban primacy. The formulas used for the calculations were introduced a one-time requirement for all communities, to ensure accuracy and speed in obtaining the required results. The functionality of a spatial information display has also been used in an encoded way to display size categories of urban settlement after the entry of these data, using quantitative population division coding and based on the classification adopted by the research.

\section{Size distribution analysis}

\section{1. A theoretical review of the methods for analysing size distribution}

In general terms can be suggested that analysis of urban system is the study of the system of towns and villages in a citiy or region in terms of spatial interaction, size and rank, spatial distribution of settlement on a regional map, distance and functional and size composition [15]. The research here focuses on one of the most important elements of urban system analysis it is the size analysis of this system, which concerns with understanding the characteristics and features of different sizes of the region's urban settlement. The importance of addressing this element stems from the fact that size can measure the value 
of a physical/urban centre based on the general premise that large human settlement centres are multifunctional, with extended impact. The larger the size, the more jobs there are; thus, the city degree of centrality and its impact in its rural and urban surroundings have increased. There are variety of literature on methods for analysing the size distribution of urban settlement, from which we can generally divide them into two basic trends: qualitative analysis methods and quantitative analysis methods. Some different trends were involved. In particular: geography (central place theory, hierarchical diffusion theory); and urban (first city law, rank and size rule). While the study of statistical analytical methods were in two parts: statistical metrics, for determining urban primacy, other metrics for determining urban settlement, and computation of urban concentration, (Figure 1).

For theoretical trends, geographically determining the relationship between urban settlement and their hierarchy emerged, with "the central place theory" of Christaller of 1933 studying the relationship between size, rank and function of the assembly (16), (17), (18), (19) and the "hierarchical diffusion theory", which appeared in the writings of Hagertranal (1953), Rerry (1972) and Redon (1975); were based on the study of interrelationships, size hierarchical, and functional hierarchical of urban settlement [14]. Studies on urban orientation In 1939, Mark Jefferson introduced "the law of the primate city", which deals with the importance of the primat city, its dominance over the urban system and the rank of the next two cities through population size [20]. In the same vein, Zipf introduced in 1949 "Size-Rank Distribution" which aims at establishing a correlation between population sizes of cities and their general rank according to these sizes [17],[21].

The methods of quantitative statistical analysis were twofold: the first of these are the measures of urban primacy, presented also by Mark Jefferson in 1939, [20] which relate to the measurement of the degree of the urban primacy, among the cities of the region, and the concomitant inequality in function and urban field. A number of the "index to measure urban primacy" have been developed, the most significant being the ratio of any city to the first city, the urban size convergence index, the urban primacy or concentration ratio, and the urban primacy index for the four cities [21], [22]. The second is the measurement of distribution the hierarchical of urban settlement and computation of function centrality, including: the Gutman scale method and Scalogram, [15], [22] Pearson correlation coefficient link and Spearman correlation coefficient [23].

By restricting the analysis of urban system in Egypt, reference literature on understanding the characteristics of the urban system in Northern Upper Egypt is still scarce. A study entitled "an urban approach to determining the role of urban system in promoting balanced development" [18], analysed the experiences of earlier developed and developing countries, with a view to deriving measurement methods that can be used to monitor the characteristics of the current urban system in the region Southern Upper Egypt region. Another study, entitled "urban sprawl of median cities and the influence of regional and social factors on its characteristics from 1976-1989" [19], An assessment of the areas of the urban sprawl of the intermediate cities - the areas most affected by urban growth - in order to determine their current population absorption potential and to determine factors affecting their rapid population growth, their correlation with the urban system and its size and functional content of urban areas and rural settlement in three governorates of the delta region, namely, Sharqiya, Daqahliyah and Kafr ElSheikh. According to a recent study entitled "patterns of spatial distribution of urban settlements - an analytical study of the Egyptian urban system" [14]; analysis of the patterns of spatial distribution of urban settlement in Egypt in terms of rank, size, spacing and function, and a proposed concept for dividing this system through local factors and variables, was carried out. The research concluded that the Egyptian system could be divided into two main types of spatial distribution of urban system, namely "aix" and "diffuse" types.

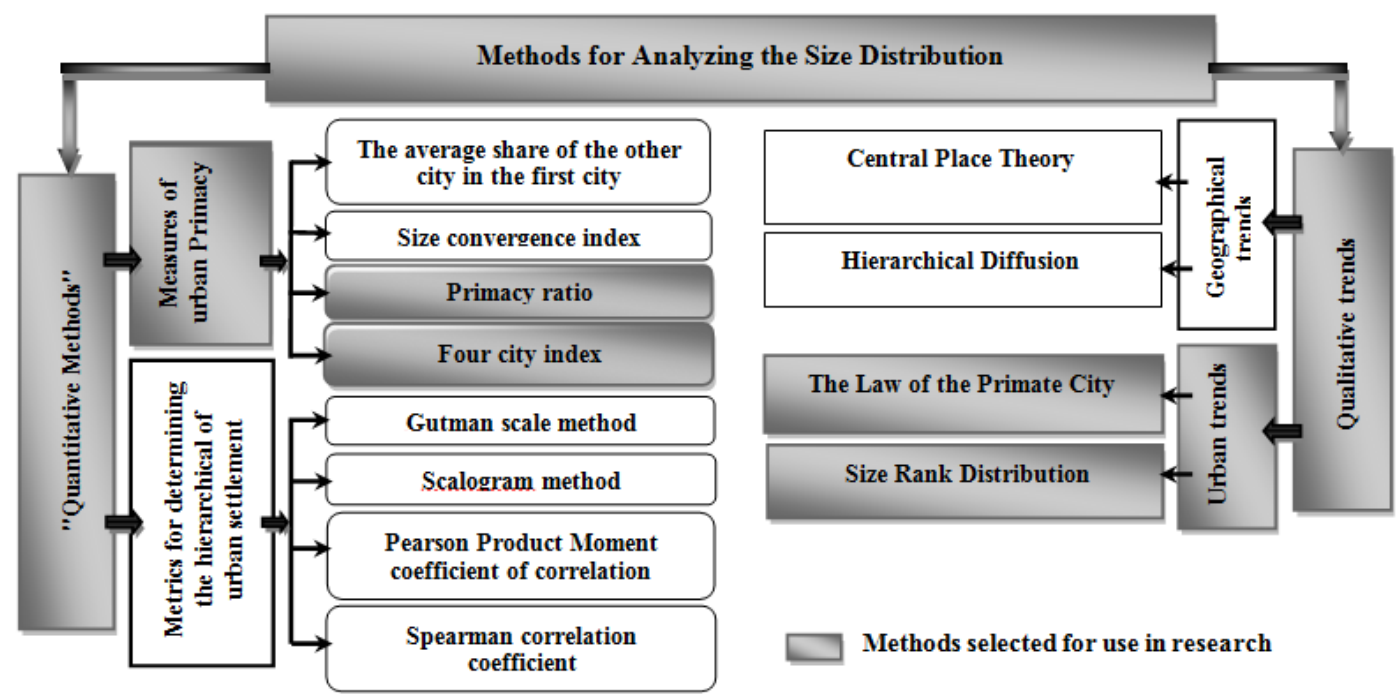

Figure 1: Theoretical Trends and Statistical/ Quantitative Methods used to Study the Size Distribution of Urban Settlements [12] 
Thus, the existence of a systematic study to analyse "urban system" in the Northern Upper Egypt Region represents a scientific addition in this area. This research considers, as part of the first research series that follows, one of the components of its analysis, namely the size distribution of the urban settlement. In order to understand the size distribution characteristics of the study area settlement, the research will begin by providing an analysis of the size and proportion of the population in the different study area size groups, followed by area size analysis using two analytical methods from each direction (from theoretical trends, urbanization will be used in "The Law of the Primate City", "Size Rank Distribution", and from analytical methods the four city index and Primacy ratio will be used.

\subsection{Size and proportion of the population of urban settlements of different size groups in Northern Upper Egypt Region}

The Northern Upper Egypt Region stands out among the regions of Egypt, being the closest to greater Cairo to the Upper Egypt region, which is highly urbanized and concentrated in services and economic activities, and is the link between the Nile delta and ribbon valley. The Northern Upper Egypt Region is characterized by its unique composition and the cultural heritage of the Nile valley in the governorates of Beni Suef and Minya. The oasis in the desert is represented by the Fayoum oasis, which is similar to the lower western desirt.

The territory administratively comprises three provinces, Minya, Beni Suef and Fayoum, with a total area of up to 70,000 $\mathrm{km}^{2}$. Two governorates are located in the Nile valley (Bani Suef $7169 \mathrm{~km}^{2}$, Minya $56587 \mathrm{~km}^{2}$ ) with a total area of about 64000 $\mathrm{km}^{2}$, while Fayoum governorate includes the low fayoum and Wadi El-Rayan governorates with an area of $6,000 \mathrm{~km}^{2(12)}$. In this study, the cities of Fayoum governorate were excluded from the northern region of upper Egypt for the above-mentioned reasons in the methodology.

Of the total population of the study area as a whole in 2016 (8.36 million) ${ }^{[* 2]}$, approximately $46.62 \%{ }^{[* 3]}$ were selected for study (major towns and villages of Minya and Beni Souif provinces). It is distributed among the seven size categories already approved in the methodology as follows: First, five categories for urban settlements (categories of less than 20, 20 50 , 50-100, 100-250, 250-500 thousands of populations). Second, two categories for rural settlements (the main ones located only within the urban periphery) (from 20-50, and greater than 50 thousands of populations). The study focused only on the main pre-urban villages being the most influential (demographic and functional) type of urban system in the region compared to other villages, because of the large size of the area and the dispersion of the villages, it is difficult to cover all the villages (Tables 1 and 2).

Table 1: Distribution of urban settlements (towns and villages) in the study area according to the population size of the regional administrative centres for 2016

\begin{tabular}{|c|c|c|c|c|c|c|c|c|c|}
\hline \multirow[b]{2}{*}{ status } & \multicolumn{5}{|c|}{ Urban settlements (1000) } & \multicolumn{2}{|c|}{$\begin{array}{c}\text { Rural settlements } \\
(\mathbf{1 0 0 0 )} \\
\end{array}$} & \multirow[b]{2}{*}{ 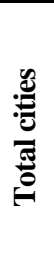 } & \multirow[b]{2}{*}{ 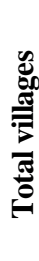 } \\
\hline & 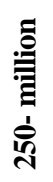 & $\begin{array}{l}\stackrel{8}{0} \\
\frac{1}{1} \\
\stackrel{8}{1}\end{array}$ & $\stackrel{\text { ஜ }}{\stackrel{1}{8}}$ & 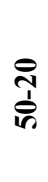 & $\begin{array}{l}\overline{3} \\
.3 \\
\text { 궁 }\end{array}$ & 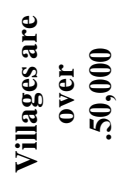 & 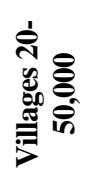 & & \\
\hline Beni Suef & 1 & - & - & - & - & - & 5 & 1 & 5 \\
\hline New Beni Suef & - & - & - & - & 1 & - & - & 1 & - \\
\hline Al Fashn & - & - & 1 & & - & - & 2 & 1 & 2 \\
\hline Al Wasta & - & - & - & 1 & - & - & 5 & 1 & 5 \\
\hline Ehnasia & - & - & - & 1 & - & - & 3 & 1 & 3 \\
\hline Biba & - & - & 1 & & - & - & 2 & 1 & 2 \\
\hline Samasta & - & - & - & 1 & - & - & 2 & 1 & 1 \\
\hline Nasir & - & 1 & - & - & - & - & 2 & 1 & 2 \\
\hline Total of Beni Suef Governorate & 1 & 1 & 2 & 3 & - & - & 21 & 8 & 21 \\
\hline Minya & 1 & - & - & - & - & 1 & 9 & 1 & 10 \\
\hline New Minya & - & - & - & - & 1 & - & - & 1 & - \\
\hline Abu qurqas & - & -- & 1 & - & - & - & 5 & 1 & 5 \\
\hline El Edwah & - & - & - & - & - & - & 1 & 1 & 1 \\
\hline Bani Mazar & - & 1 & - & - & - & - & 7 & 1 & 7 \\
\hline Dayr Mawas & - & - & 1 & 1 & - & 1 & 2 & 1 & 3 \\
\hline Samalut & -- & 1 & - & - & - & - & 9 & 1 & 9 \\
\hline Matay & - & - & 1 & 1 & - & - & 2 & 1 & 2 \\
\hline Maghaghah & - & - & 1 & - & - & - & 8 & 1 & 8 \\
\hline Mallawi & & 1 & - & - & - & - & 13 & 1 & 13 \\
\hline Total of Minya Governorate & 1 & 3 & 4 & 2 & 1 & 2 & 56 & 10 & 58 \\
\hline Total of Beni Suef \& Minya Governorate & 2 & 4 & 6 & 5 & 1 & 2 & 77 & 18 & 79 \\
\hline
\end{tabular}


Table 2: Ratios of urban settlement (cities\& rural) in the study area and their population by size groups in the 2016 census

\begin{tabular}{cccccccc}
\hline Settlement Size & $\begin{array}{c}\text { Size Categories } \\
\text { (Thousand People) }\end{array}$ & Number & \%Number & Population & $\begin{array}{c}\text { \%Population } \\
\text { Average population } \\
\text { (People) }\end{array}$ \\
\hline & million-250 & 2 & 2.06 & 553333 & 14.19 & 276.666 \\
Urban Settlements (Cities) & $250-100$ & 4 & 4.12 & 515102 & 13.21 & 128.775 \\
& $100-50$ & 6 & 6.19 & 447118 & 11.47 & 4.90 & 38.241 \\
& $50-20$ & 5 & 5.15 & 191206 & 6.15 & 6.032 \\
\hline \multirow{2}{*}{ Urban Settlements (Rural) } & less than 20 & 1 & 1.03 & 6032 & 144096 & 3.70 & 72.048 \\
\hline & More than 50 & 2 & 2.06 & 79.38 & 26.526 \\
\hline
\end{tabular}

Source: CAPMAS, 2016 Census [24] (at the disposal of researchers).

Analysis of the urban Settlement during these different sizes shows the following:

- The first group to the (City population 250-million of populations): This group includes the largest cities (the largest population group), which constitute a high concentration of population in the study area. In 2016, approximately $14.19 \%$ of the study area's population was inhabited by 553,333 inhabitants. With an average population of 276,666 population /settlement, this group represents the cities of Beni Suef and Minya.

- The second group to the (City population 100-250 thousand people): consists of the four largest cities, with 515,102 residents, representing $13.21 \%$ of the study area's population in 2016 , with a population average of 128,775 population /settlement, this group represents the city of Malawi, Samalut, Nasir and Bani Mazar.

- The third group (City population 50-100 thousand people): includes the intermediate 6 cities, with 447,118 residents and $11.47 \%$ of the study area's population in 2016 , with an average population of 74,519 population /settlement, this group represents the city of El-Fashn, Biba, Maghagha, Abu Qurqas, Matay and Dayr Mawas.

- The fourth group, (City population 20-50 thousand people): includes the 5 smaller cities settled by 191,206, representing $4.90 \%$ of the study area's population in 2016, with an average population of 38,241 Population /settlement, This group represents the new city of Samasta, Al Wasta, Ehnasia, Al Edwah, Beni Suef.

- In the fifth group of (cities less than 20000 thousand people): we represent one city, the city of New Minya, with 60,320 Population, and representing $0.15 \%$ of the study area's total population in 2016. A population average of 6,032 population /settlement.

- The sixth group of (village more than 50 thousand people): represents two mega-villages, the village of Dalija, in Dayr Mawas city, and Telah village in Minya city, with a population of $144,096 \%$, representing $3.70 \%$ of the total population of the study area in 2016, with an average population of 72,048 population /settlement.
- The seventh group of (village 20-50 thousand people): They constitute the most numerous rural settlements in the study area, accounting for $79.38 \%$ of the total number of settlements in the area, and settling in $52.38 \%$ of the total population in the area in 2016, with an average population of 26,526 Population /settlement. And so has been distributed to all the centres in the study region but is increasingly concentrated in the Minya provincial cities (Malawi city, Minya, Samalut, Abu Qurqas accounted for 35.54, 32.89, 31.07 and $25.92 \%$ respectively of the total number of rural settlement in study governorates) ${ }^{[* 4]}$.

Analysis of the figures in the two previous (Tables 1, 2) and (Figure 2) shows the following:

- Most urban settlements are concentrated in the village group of (the 20,000 to 50,000 populations), probably because the vast majority of these villages have grown on a poorly productive rural economy based on land production around the colony produces. It should be noted that the study focused only on the main villages, which are located in the periphery of cities, have the greatest impact (in terms of population weight) on the existing urban system in the territory compared with the other villages, and also because of the large size of the area and the dispersed nature of the villages, it is difficult to cover all the villages.

- urban settlements, a group of 18 urban city, $18.55 \%^{[* 5]}$ of the total number of study area, comprises two cities with a size of 250,000 and a population of 500,000, Minya (capital of the region) and Beni Suef (capital of the governorate), which, because of their job opportunities and cultural upgrading, have attracted people from within the region and helped to expand their population size, Four large cities with a population size of 100,000 to 250,000(the cities of Malawi, Nasser, Samalut and the Bani Mazar, all with a large population weight), six cities with a size of 50,000 to 100,000 were named (these cities spread over the district and are all the capital cities of study area administrative centres They are Al Fashn, Biba, Nasir, Abu Qurqas, Dayr Mawas,, Matay and Maghagha), five medium-sized cities of 20,000 to 50000 people (all also the capital of study area 


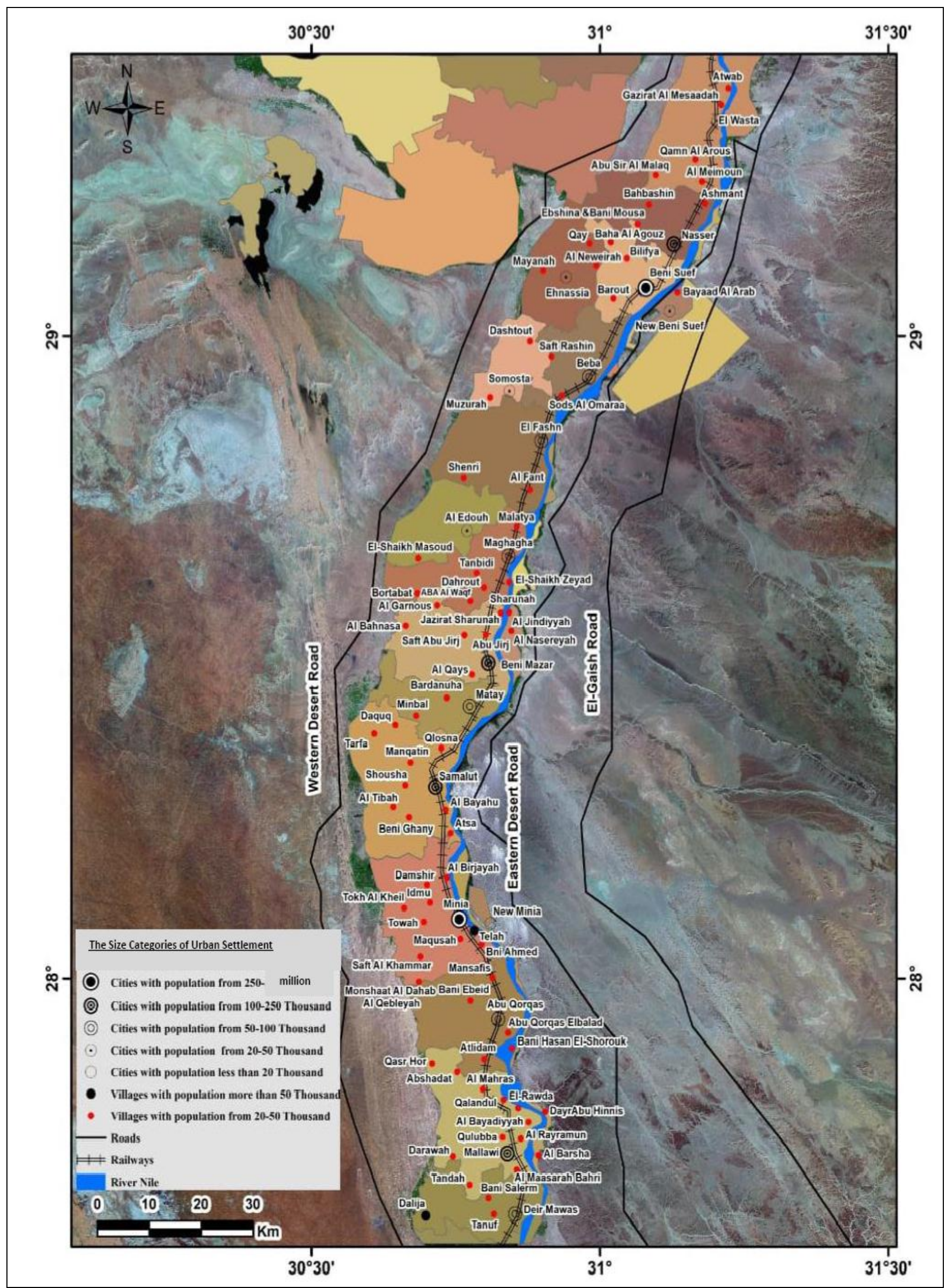

Figure 2: Analysis of the Size Distribution of Urban Settlements in Northern Upper Egypt Region ( in the 2016 census). 
administrative centres, namely, Al Wasta, Ehnasia, Samasta, Al Edwah, Beni Suef), and one small city - less than 20,000 of them - (this category is represented by the new city of Minya).

- The largest percentage of rural settlements in the study area, including the large villages ${ }^{\left[6^{*}\right]}(20,000$ to 50,000$)$. They constitute $79.38 \%$ of the number of settlement in the study area, followed by the mega-villages $(2.06 \%$ of the number of settlement in the area). It is represented by the village of Dalija, Dayr Mawas city, and Telah village, Minya city, all of which are local units. The reduction in the population of these villages, despite the important administrative function they perform, can be justified by the fact that they fall into a cluster of villages that converge.

- In addition, we note the absence of the upper size group (above a group larger than 1 million), where the first city of the region is located (Minya), whereas in the third size group, (the group 250,000 to 500,000), preceded by two large groups, cities larger than the million, cities of 500,000 to 1 million - up to 301,823 inhabitants in the 2016 census.

- There is an inverse relationship between the number and size of the settlement, we note that the picture of population concentration in urban settlement is that a high percentage of the number of rural settlements, (such as huge, medium villages), constitute $81.44^{\left[7^{*}\right]}$ of the number of urban settlement in study region, including a low percentage of the population of $65.62 \%^{\left[{ }^{*}\right]}$. In other words, a low proportion of the number of urban settlements (large cities account for $6.19 \%$ of the number of urban settlements) has a high proportion of the population (27.4\% of the total population ${ }^{\left[{ }^{* *}\right]}$ and concentration increases with the addition of small and medium-sized cities, amounting to $43.92 \%$ of the total population of the study region concentrated in $18.55 \%$ of the number of urban settlements.

As we have already pointed out, relying on "the size analysis theories of urban settlements", the research is dealing with size analysis as one of the most important element of the urban system and that's through:

- Rank and size analysis using "The Law of Primate City" and "The Size-Rank Distribution".

- To analyses "Urban Primacy" between the region's cities using the "Four City Index", and the "Primacy Ratio".

${ }^{\left[{ }^{* 1}\right]}$ Difference coefficient $=$ (standard deviation of total provincial density / arithmetic mean)* 100

${ }^{\left[{ }^{2}\right]}$ The total population of the study area in $2016=$ the total size of urban settlements (urban and rural) of the city of Minya + the total size of urban settlement (urban and rural) of the province of Beni Suef $=5.379 .689+$ 2.984.071=.8.363.670

[*3] The total population of the cities and villages selected for study in 2016/total population of the study area* $100=899436 / 8363670 * 100=\% 46.62$

${ }^{\left[{ }^{4}\right]}$ The size of rural settlements of the city of Malawi is 725.082 , the size of rural agglomerations of the city of Minya is 671.846 , the size of rural settlements of the city of Samalut is 634.719and the size of rural settlements of the city of Abu Qurqas is .529.436, By dividing it by the total size of the rural settlements 2.042.549, we obtain the proportions mentioned above.

${ }^{\left[{ }^{5}\right]}$ Pooled urban settlement in cities size group $=2.06 \%+4.12 \%+6.19 \%+5.15 \%$ $+1.03 \%=18.66 \%$

${ }^{[*]}$ They are: Dalija, Telah, Bilifya, Ebshina \&Bani Mousa, Barout, Baha Al Agouz, Bayaad Al Arab, Al Fant, Shenri, Atwab, Al Meimoun, Qamn Al Arous, Abu Sir Al Malaq, Gazirat Al Mesaadah, An Neweirah, Qay, Mayanah, Saft Rashin, SoDs Al Omaraa, Muzurah, Dashtout, Ashmant, Bahbashin, Al Birjayah, Bni Ahmed Gharbia, Saft Al Khammar, Tokh
Al Kheil, Idmu, Damshir, Towah, Maqusah, Monshaat Ad Dahab Al Qebleyah, Atlidam, Bani Ebeid, Abu Qurqaz, Bani Hasan, El-Shorouk, Mansafis Abiouha, El- Shaikh Masoud, Abu Jirj, Al Garnous, Al Qays, Al Bahnasa, Al Gharbeyah WA Kafr Al Mansourah, Al Jindiyyah, An Nasereyah(Al Garabia Previous), Saft Abu Jirj, Bani Salern, Tanuf, Atsa, Shousha, Qlosna, Manqatin, At Tibah Al Bayahu, Bani Ghani, Daquq, Tarfa, Bardanuha, Minbal, ABA Al Waqf, Sharunah, Tanbidi, El- Shaikh Zeyad, Bartabat, Jazirat Sharunah, Dahrout, Malatya, Abshadat, Al Barsha, El-Rawda, Tandah, DayrAbu Hinnis, Qalandul, Al Bayadiyyah, AR Rayramun, Al Mahras, Al Maasarah Bahri, Darawah, Qasr Hor, Qulubba.

${ }^{\left[{ }^{* 7}\right]}$ Number of rural settlements $=$ mega-villages + hamlets, $\% 2.06+$ $\% 79.38=\% 81.44$

${ }^{\left[{ }^{8} 8\right]}$ Population of rural settlements (mega-villages + hamlets $=\% 4.24+\% 52.38=$ $\% 65.62$

${ }^{\left[{ }^{*}\right]}$ Population of urban settlements/ cities $=16.34+13.21=27.4 \%$

\subsection{Rank and size analysis}

Mark Jefferson in 1939 introduced the Law of Primate City as a starting point for city rank and size analysis, taking care of the importance of large cities in the urban system for any region and the rank of the next two cities in size. He noted (from his study of a group of cities in the 1930s) that the median value of the population of the second city was $30 \%$ of the population of the first (larger) city, The third city has $20 \%$ of the population of the first city [19]. The largest credit is due to "G. K. Zipf", in which he concluded in 1949 that there is a correlation between the city population size and the overall order of size. If cities in a region rank in descending order by population, the size of a city is $1 / n$ larger, according to series $1,1 / 2,1 / 3,1 / 4, \ldots 1 / \mathrm{n}$ [17].

Applying these rules to the study region in order to determine whether there is a correlation between ranks, sizes and Numbers of cities in the study region, the following observations were made: (Table 3 and Figure 3):

- In 2016, Minya ranked first, with the largest urban population in the region, while Beni suef ranked second and accounted for $83.33 \%$ of the first city's population. It is therefore relatively far from the theoretical size assumed by Jefferson (30\%) and zipf $(50 \%)$.

- Mallawi was ranked third with $60.60 \%$ of the total population of the first city of the region and is also far from the theoretical size assumed by Jefferson and zipf

- The rest of the cities of the region are quite distant from the assumed population sizes of Jefferson and Zipf such as the city of Nasir, Bani Mazar, Maghagha, Al Fashn, Abu QUrqas and Matay, some more akin to the theoretical size of zipf such as the Al Edwah, and the new Beni Suef.

We can say that the size of the settlement in the study region does not correspond to the Size- Rank Distribution. There is even a gradient that is evident from a comparison of the size of the first city (Minya) with that of the last city (New Minya), which was 1/51 of the size of the city of Minya and ranked according to the rule of Size- Rank Distribution 1/18.

On the evolution of the ranks of the cities over the years 76, 86, 96, 2006, 2016 (Table 4) (Figure 4), we can conclude:

- Uneven population growth rates of the various population groups varied from 1976 to 2016, indicating that the population growth rate in the region generally rose during successive periods but varied from time to time depending on the influence of natural growth factors and migration. 
Table 3: Order of size of urban settlements (Cities) with more than 100,000 populations (2016), expected theoretical size of each according to the Jefferson "The Law of Primate City", "Size- Rank Distribution" of Zipf

\begin{tabular}{|c|c|c|c|c|c|c|c|}
\hline \multirow[t]{2}{*}{ No } & \multirow[t]{2}{*}{$\begin{array}{c}\text { urban settlements } \\
\text { (Cities) }\end{array}$} & \multicolumn{2}{|c|}{$\begin{array}{l}\text { Population and actual } \\
\text { percentages, } 2016\end{array}$} & \multicolumn{2}{|c|}{$\begin{array}{l}\text { Population and theoretical ratio } \\
\text { according to Jefferson's "The } \\
\text { Law of Primate City" }\end{array}$} & \multirow{2}{*}{\multicolumn{2}{|c|}{$\begin{array}{c}\text { Population and } \\
\text { theoretical ratio by } \\
\text { "Size- Rank } \\
\text { Distribution" of Zipf }\end{array}$}} \\
\hline & & Population & $\%$ & Population & $\%$ & & \\
\hline 1 & Minya & 301823 & 100.0 & 100.00 & 301823 & 301823 & 100.00 \\
\hline 2 & Beni Suef & 251510 & 83.33 & 30.00 & 90546.9 & 150911.5 & 50.00 \\
\hline 3 & Mallawi & 182921 & 60.60 & 20.00 & 60364.6 & 100597.6 & 33.33 \\
\hline 4 & Samalut & 117231 & 38.84 & 14.20 & 42858.8 & 75455.7 & 25.00 \\
\hline 5 & Nasir & 111602 & 36.97 & 11.10 & 33502.3 & 60364.6 & 20.00 \\
\hline 6 & Bani Mazar & 103348 & 34.24 & 9.09 & 27435.7 & 50313.8 & 16.67 \\
\hline 7 & Maghaghah & 98262 & 32.55 & 7.60 & 22938.5 & 43130.5 & 14.29 \\
\hline 8 & Al Fashn & 85391 & 28.29 & 6.60 & 19920.3 & 37727.8 & 12.50 \\
\hline 9 & Biba & 75177 & 24.90 & 5.20 & 15694.7 & 30182.3 & 10.00 \\
\hline 10 & Abu Qurqas & 74794 & 24.78 & 5.80 & 17505.7 & 33532.5 & 11.11 \\
\hline 11 & Matay & 60855 & 20.16 & 4.70 & 14185.6 & 27435.7 & 9.09 \\
\hline 12 & Dayr Mawas & 52639 & 17.44 & / & I & 25141.8 & 8.33 \\
\hline 13 & Samasta & 49494 & 16.39 & l & l & 23210.1 & 7.69 \\
\hline 14 & Al Wasta & 49288 & 16.33 & l & / & 21550.1 & 7.14 \\
\hline 15 & Ehnasia & 48344 & 16.01 & 1 & l & 20131.5 & 6.67 \\
\hline 16 & New Beni Suef & 23405 & 7.75 & I & I & 18863.9 & 6.25 \\
\hline 17 & Al Edwah & 20675 & 6.85 & / & / & 17747.1 & 5.88 \\
\hline 18 & New Minya & 6032 & 1.99 & / & / & 16781.3 & 5.56 \\
\hline
\end{tabular}

Source: CAPMAS, 2016 Census [25] (at the disposal of researchers).

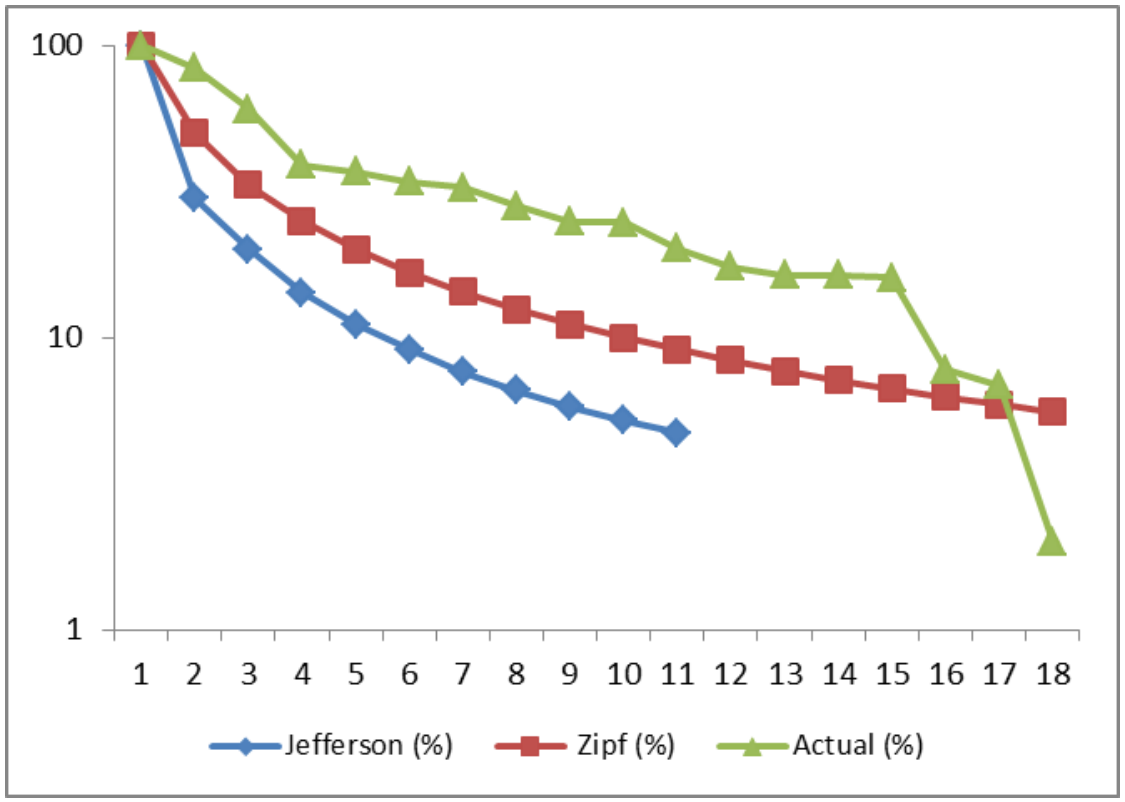

Figure 3: Variation in population sizes between theoretical and actual urban settlements in the study region, 2016 Source: prepared by researchers based on tabular data [3]. 
Table 4: Evolution of Rank of urban settlements in the study region from 1976 to 2016

\begin{tabular}{|c|c|c|c|c|c|c|c|c|c|c|c|}
\hline \multirow{2}{*}{$\begin{array}{l}\text { Size Categories } \\
\text { (Population) }\end{array}$} & \multirow{2}{*}{ City } & \multicolumn{2}{|c|}{1976} & \multicolumn{2}{|c|}{1986} & \multicolumn{2}{|c|}{1996} & \multicolumn{2}{|c|}{2006} & \multicolumn{2}{|c|}{2016} \\
\hline & & Population & Rank & Population & Rank & Population & Rank & Population & Rank & Population & Rank \\
\hline \multirow[b]{2}{*}{$\begin{array}{l}\text { From } 250,000 \\
\text { to million }\end{array}$} & Minya & 146,423 & 1 & 179,060 & 1 & 201,440 & 1 & 236,043 & 1 & 301.823 & 1 \\
\hline & Beni Suef & 118,148 & 2 & 152,476 & 2 & 171,734 & 2 & 193,048 & 2 & 251.510 & 2 \\
\hline \multirow{4}{*}{$\begin{array}{c}\text { From } 100 \text { to } \\
250,000\end{array}$} & Mallawi & 74,256 & 3 & 98,632 & 3 & 119,285 & 3 & 139,929 & 3 & 182.921 & 3 \\
\hline & Samalut & 48,146 & 4 & 62,404 & 4 & 75,437 & 4 & 91,475 & 4 & 117.231 & 4 \\
\hline & Nasir & 40,151 & 5 & 54,655 & 5 & 70,543 & 5 & 85,319 & 5 & 111.602 & 5 \\
\hline & Bani Mazar & 39,373 & 7 & 47,982 & 7 & 52,690 & 7 & 79,553 & 6 & 103.348 & 6 \\
\hline \multirow{6}{*}{$\begin{array}{c}\text { From } 50,000 \text { to } \\
100,000\end{array}$} & Maghaghah & 40,102 & 6 & 50,916 & 6 & 60,405 & 6 & 75,657 & 7 & 98.262 & 7 \\
\hline & Al Fashn & 23,506 & 9 & 43,488 & 9 & 52,589 & 8 & 65,621 & 8 & 85.391 & 8 \\
\hline & Biba & 33,047 & 10 & 40,668 & 10 & 49,516 & 10 & 57,716 & 10 & 75.177 & 9 \\
\hline & Abu Qurqas & 33,498 & 8 & 43,765 & 8 & 50,031 & 9 & 57,892 & 9 & 74.794 & 10 \\
\hline & Matay & 21,101 & 11 & 29,027 & 11 & 36,953 & 11 & 46,903 & 11 & 60.855 & 11 \\
\hline & Dayr Mawas & 20,058 & 12 & 26,641 & 13 & 33,197 & 12 & 40,640 & 12 & 52.639 & 12 \\
\hline \multirow{5}{*}{$\begin{array}{c}\text { From } 20,000 \text { to } \\
50,000\end{array}$} & Samasta & 17,202 & 14 & 23,958 & 15 & 30,714 & 15 & 37,965 & 13 & 49.494 & 13 \\
\hline & Al Wasta & 17,659 & 13 & 27,269 & 12 & 30,879 & 14 & 37,916 & 14 & 49.288 & 14 \\
\hline & Ehnasia & 16,453 & 15 & 23,970 & 14 & 31,488 & 13 & 37,174 & 15 & 48.344 & 15 \\
\hline & New Beni Suef & - & & - & & 8,106 & 17 & 17,921 & 16 & 23.405 & 16 \\
\hline & Al Edwah & 7,146 & 16 & 10,349 & 16 & 13,553 & 16 & 15,875 & 17 & 20.675 & 17 \\
\hline $\begin{array}{c}\text { Less than } \\
20,000\end{array}$ & New Minya & - & & - & & 1,102 & 18 & 4,567 & 18 & 6.032 & 18 \\
\hline
\end{tabular}

Source: CAPMAS, 76, 86, 96, 2006, 2016 Census [25], [26] (at the disposal of researchers).

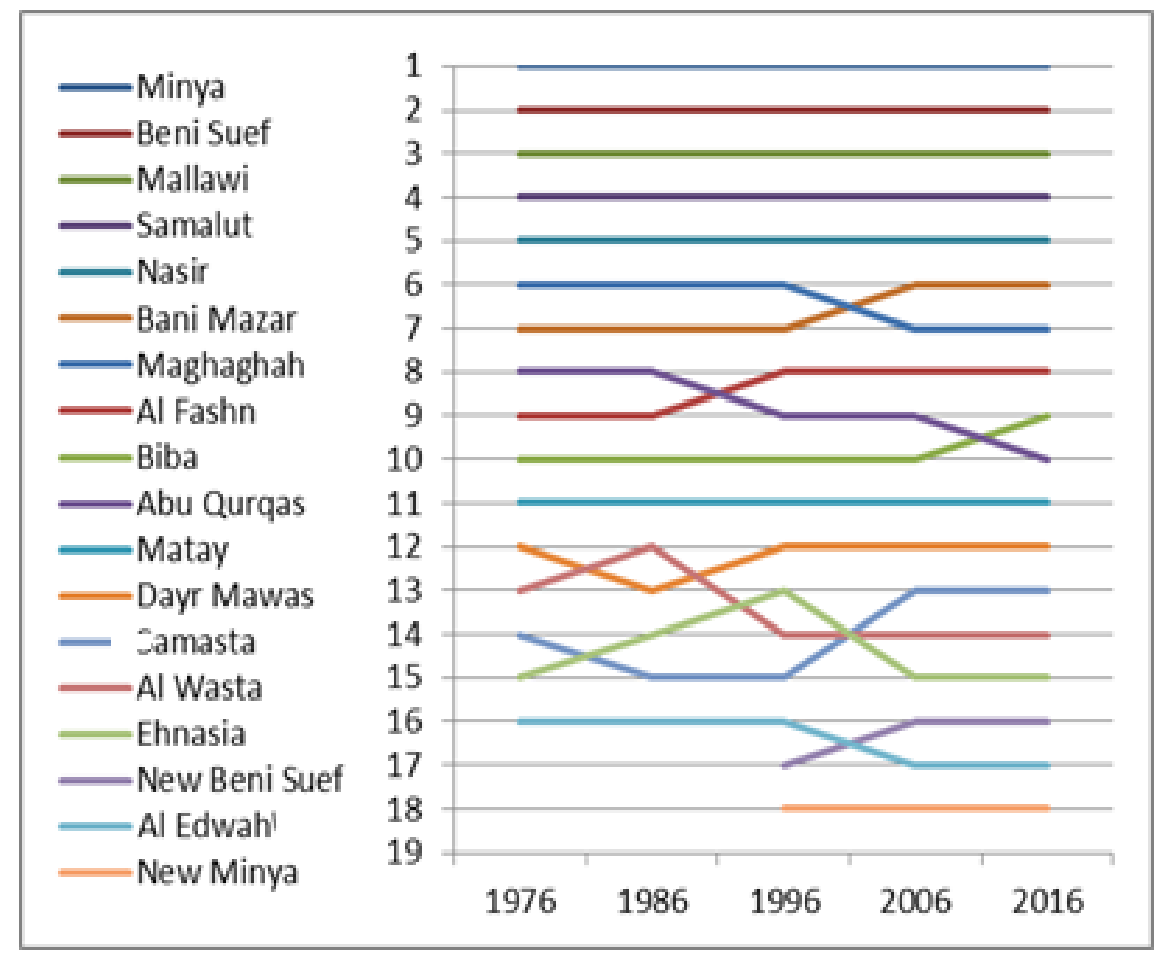

Figure 4: Evolution of Ranks of urban settlements in the study region from 1976 to 2016 
Changes in the order of size of some of the regional urban centres and, consequently, the size order has taken different forms in terms of stability or variability, indicating that the size system was affected by many developmental and demographic changes from 1976 to 2016, owing to factors that contributed to the high population growth rates in cities at the expense of others, such as location, roads.

- The large size categories of cities maintained their rank; this reflected cities' ability to dominate urban areas_under weak competition from other urban centres because of their functional characteristics and characteristics (functional diversity), their ability to attract populations and their enjoyment of development projects, which had led to the establishment of numerous activities and investments, as well as the availability of employment, the improvement of health and education services, facilities and better living standards.

- The smaller size categories of cities have fluctuated upward and downward rank, most being new cities (such as the new city of Beni suef, New minya) and other smaller developing cities (such as the cities of Ehnasia, Samasta and Al Wasta central) with a small population, so smaller cities were clearly and rapidly affected in rank, This is evident in both Ehnasia and central and Samasta, which have had fluctuations in rank and size and sometimes even decreased in rank, which can be explained by their high population growth resulting from increased internal migration from rural settlements to these urban centres and their natural rate of increase in time. The decline in those ranks has also in other periods been due to their low population growth rate, and this decline in population growth rates may be explained by the fact that these cities are no longer as attractive to the population as they were in earlier periods. In addition, residents search for investment areas in neighboring centers that have distinctive characteristics in terms of population attraction from other centers (such as the city of Bani suef, Biba, and Al Fashn) nearby with high population weight. This may also be due to their employment and investment problems.

- The cities of the first size categories (250,000 to million) were consistently ranked in 1976-2016, with Minya taking first place in terms of population size, followed by Beni Suef.

- The second size categories (100,000-250,000) also stood firm in its ranking from 1976 to 2016 in most of its cities, Mallawi, Samalut and Nasier, excluding Bani Mazar city, which rose from 7th in 1996 to 6th in 2016.

- The third size categories (50,000-100,000) had minor fluctuations in rank, including the cities of Maghaghe, Al fashn, BIba, Abu Qurqas, Matay and Dayr Mawas. Maghaghe rank decreased from rank 6 in 1996 to rank 7 in 2016 with the change in rank and size predominant. For example, $\mathrm{Al}$ Wasta

- city was ranked 13, 12, 14 and 14 according to the 1976, 1986, 1996, 2006 censuses, respectively.

- The fourth size category $(20,000-50,000)$ predominates in rank and size. For example, the city of Ehnasia ranked 15,
$14,13,15$ and 15 according to the 1976, 1986, 1996, 2006, 2016 censuses, respectively.

- The fifth size category (cities less than 20,000) is represented by one city - New Minya - which is a developing city.

\section{4. Urban Primacy analysis}

The analysis of "urban Primacy" measures the degree of variability in size among the region's cities and, consequently, the homogeneity of the urban system. The result of this analysis indicates the degree of concentration of services and economic activities in the cities of the territory, which is critical in guiding and propelling the development processes of the territory.

Using the urban Primacy index for the four metropolitan cities [22], [23] the predominance of the first city is determined only for the following four cities, which can be calculated using the following formula: UP $=\mathrm{c} 1 /(\mathrm{c} 2+\mathrm{c} 3+\mathrm{c} 4)$, UP $=$ urban primacy index, $\mathrm{c} 1=$ population of the first (greater) city, $\mathrm{c} 2, \mathrm{c} 3$, $\mathrm{c} 4$ = population of the (second + third + fourth) city. If the primacy index value of more than one is correct, this indicates that the population of the first city is higher than the population of the three cities combined, an indication of the dominance of the first (primate) city as compared with the other three cities. In general, index values fluctuate around one valid in developed countries, while in developing countries the value increases, and that shows the growing importance of the first (primate). The indicator is flawed by its focus on the relationship between the first four cities only, its focus on variables in population size, and the neglect of variables in function and distance.

Given the region of study, the size of the urban aggravation varies, but it is noticeable that not a single city primate the urban system, as there is some rivalry between the provincial capitals (Minya and Beni Suef). Despite the years that have passed, the new towns (New Minya and New Beni Suef) have not been able to function as they have been built, even they have been built since several years. Using the "Four City Index", a ratio of 0.55 to the next three cities was observed to be Minya, less than one true, indicating no urban Primacy in the region, (Table 5).

Using another measure, the "Primacy Ratio" (ratio of urban population to the first city/urban population of the second city) and its calculation in the North Upper region between 1976 and 2016, we also note that this ratio is low and does not reflect the extent of the control of the city of Minya (first city) over the city of Beni Suef (second city), although it increased slightly from 1.17 to 1.22 between 1986,2006 and decreased slightly between 2006 and 2016, decreasing from 1.22 to 1.20 respectively, as shown in (Table 6).

Considering the size of the cities of Northern Upper Egypt in the various censuses from 1976 to 2016, the range between the size of the first and last cities of the region is constantly increasing, which means that the first "Minya" is increasing in size at the expense of smaller towns, (Table 7). 
Table 5: Shows the relative importance of urban settlements (Towns) in the North Upper region in 2016

\begin{tabular}{ccccc}
\hline Towne & Rank & 2016 population & $\begin{array}{c}\text { Four City } \\
\text { Index }\end{array}$ & $\begin{array}{c}\text { \% Of the total urban population } \\
((\mathbf{1 7 1 , 2 7 9 1} \text { per cent })\end{array}$ \\
\hline Minya & 1 & 301823 & 0.55 & 17.62 \\
Beni Suef & 2 & 251510 & 0.61 & 14.68 \\
Mallawi & 3 & 182921 & 0.55 & 6.84 \\
Samalut & 4 & 117231 & 0.37 & 6.52 \\
Nasir & 5 & 111602 & - & 6.03 \\
Bani Mazar & 6 & 103348 & - & 5.74 \\
Maghaghah & 7 & 98262 & - & \\
\hline
\end{tabular}

Source: CAPMAS, 2016 Census [24], [25] (at the disposal of researchers).

Table 6: Progress in the rate of urban concentration in the governorates of Minya and Beni Souif from 1976 to 2016

\begin{tabular}{ccccccc}
\hline Towne & Rank & Population, 1976 & Population, 1986 & Population, 1996 & Population, 2006 & Population, 2016 \\
\hline Minya & First & 146,366 & 179,060 & 201,440 & 236,043 & 301.823 \\
Beni Suef & Second & 117,910 & 152,476 & 171,734 & 193,048 & 251.510 \\
"Primacy Ratio" & 1.24 & 1.17 & 1.17 & 1.22 & 1.20 \\
\hline
\end{tabular}

Source: CAPMAS, 2016 Census [24], [25] (at the disposal of researchers).

Table 7: Development of range between the largest and smallest city in the North upper region during the 1976-2016 period

\begin{tabular}{cccccc}
\hline & \multicolumn{2}{c}{ The Frist Town } & \multicolumn{2}{c}{ The Last Town } & \multirow{2}{*}{ Range } \\
\cline { 2 - 5 } & Towne & Population & Towne & Population & \\
\hline 1976 & Minya & 146,366 & Al Edwah & 7,146 & 139,22 \\
1986 & Minya & 179,060 & Al Edwah & 10,349 & 168,71 \\
2006 & Minya & 201,440 & Al Edwah & 13,553 & 220,16 \\
2016 & Minya & 236,043 & Al Edwah & 15,875 & 281.14 \\
\hline
\end{tabular}

Source: CAPMAS, 2016 Census [24], [25] (at the disposal of researchers). My New Mina city and New Beni Suef have been ruled out 


\section{Conclusions and Recommendations}

The results of the analysis of the seven size categories in the study region in 2016 are as follows:

1. Regional importance and job creation are the main reasons why cities of a size (250,000-million of population) reach that size and represent the capitals of provinces such as Minya and Beni Suef, with large population burdens and more jobs than neighboring cities.

2. All cities that form capitals of administrative centers and have a similar managerial function fall into either the size group (100,000-250,000 of population), the size group (50,000-100,000 of population) or the size group $(20,000$ 50,000 of population). Their occurrence in different categories may be due to some other factors, such as the different degree of urban primacy of each of these cities (over neighboring cities), or a degree that characterizing the geographical location of those cities, since these sizes are the final product of the interplay of a number of geographical, cultural and economic controls that influence a pattern distribution and size of centers of urban settlement.

3. New cities (New Beni Suef and New Minya) were located in the two smaller size categories: $(20,000-50,000$ of population) and (less than 20,000 of population), the first city fell into the fourth size category $(20,000-50,000$ of population) and the second into the fifth size category (less than 20,000 of population), owing to the desert nature of those cities.

4. Rural communities with a category (over 20,000 of population) in the study region are all local units; and this has resulted in larger sizes than other villages with fewer than 20,000 of population. These rural settlements constitute $81.44 \%$ of the total number of urban settlements in the study region in 2016, including the large villages $(20,000-50,000$ of population), which account for $79.38 \%$ of the population of the region, followed by mega-villages (over 50,000 of population) and $2.06 \%$ of the number of settlements in the region (namely, the villages of Dalija, Dayr Mawas neighboring rural areas). Although the number of such settlements is increasing, they make up the smaller proportion of the population of the region $(56.08 \%)$ because these villages, while important in administrative function, are part of a group of smaller villages with which they are close and which prevent their inhabitants from migrating or even from smaller villages to be cities.

5. The inverse relationship between population and size in the region indicates that both service and economic activities are highly concentrated in large cities. About $56.08 \%$ of the study area's population resides in rural settlements (megaand large villages), which make up $81.44 \%$ of the region's population, while $43.92 \%$ is concentrated in urban settlements (large, medium, and small cities), which account for only $18.55 \%$ of urban settlements.

6. According to rank and size analysis of urban settlements in the study region in the years 1976 to 2016; we found that the size of urban settlements in the study region did not correspond to "Rank- Size Ruler". There is even a sharp decline and variation in size and rank of the cities of the region, where the variation appears large in the ranks taken by urban settlements, as can be seen from a comparison of the size of the first city (Minya) with that of the last city (New Minya), which is 1/51 times the size of Minya while having a rank at the base of rank 1/18. This confirms the concentration of economic and social development in the megacities and the delayed delivery of services to small and secondary-sized cities have been delayed, resulting in small and secondary cities losing their population to large cities, without being able to attract exodus from neighboring rural areas.

An analysis of the relationship between the ranks and sizes of the study region cities from 1976 to 2016 shows:

7. The size category of the large cities - 250,000-million in size - stood out in their order of rank, as in Minya, Beni Suef (which ranked first and second, respectively). On the other hand, the increased change in city orders was seen in the smaller segments - the fourth tier with a size group of 2050,000. The cities of this segment fluctuated considerably, including the cities of Samasta, Al Wasta, Ehnasia, New Beni Suef, and Al Edwah. For example, the city of Ehnasia ranked $15,14,13,15$ and 15 according to the 1976, 1986, 1996, 2006, 2016 censuses, respectively. All of this demonstrates that small and secondary cities have lost their populations because of the concentration of economic and social development in the large cities, making them unattractive to the population. In addition to other problems, such as poor infrastructure, rising housing prices, the lack of employment opportunities that helped to make these cities extinct.

According to the analysis of the urban primacy of urban settlements in the study region from 1976 to 2016, we conclude that:

8. The lack of high urban primacy at the regional level, owing to some rivalry between the provincial capitals of the region (Minya- Beni Suef). The highest degree of primacy in the region was in Minya city in the province of Minya and did not reach the right one $(0.55)$, with the Primacy index for all other cities approaching. This means that the region's cities lack dynamic economic and service interaction, making them more stable and stable.

9. Although no city primacy the territory, it examines the range between the size of the first and last city of the territory is constantly increasing reflects the fact that large and major cities continue to increase in size at the expense of smaller ones, which are more attractive to development and population than smaller ones.

10. The urban structure shows a clear overlap between rural and urban areas in terms of population size up to the size of the population groups $(30,000$ populations). This situation rises to 50,000 , meaning that there are many urban settlements 
that are in fact only large villages, thus weakening their role as urban centers, which, although dominated by the sector, are growing to the surrounding areas and which may be even larger in size. The only difference between these urban settlements and the other large villages is that there is a police station, even though it is dominated by the agriculture sector.

In the light of those findings, the research recommends that:

1. Ensure that the future development process corresponds to the characteristics of the existing form of development in terms of the size, number and rank of the urban settlements, in the Northern Upper Egypt region.

2. Accelerating the development of the new cities, given their great capacity to spread development, as they are a good tool for correcting the urban system imbalance in terms of size, function and location.

3. Raising the administrative rank of large villages such as Dalija village in the Dayr Mawas center, Tandah village in the Mallawi center, Muzurah village in the Samasta center, Telah in the Minya center to the small or secondary towns segment so that they could be provided with services for themselves and their rural surroundings, This makes it eligible to play effective roles in the balance of the urban system.

4. Development of the region's small and intermediate cities ${ }^{[1 *]}$, such as Al Edwah city, New Minya, New Beni suef, which act as a bridge between rural and urban development by being a center of services and marketing and a center of cultural and technological radiation.

5. Supporting economic and service activity in the cities of Minya and Beni Suef in order to meet the needs of the large urban and rural population of $14,89628,000^{\left[2^{*}\right]}$ in 2016 .

${ }^{\left[{ }^{*} 1\right]}$ Many researchers consider secondary cities of different sizes to be effective tools for achieving urban development goals generally aimed at balancing urban system, reducing population concentration in large cities and reducing regional disparities.

${ }^{\left.{ }^{* 2}\right]}$ Using the "Breaking Point Theory" in the following equation: D / $1+$ (PG/PS), where PG: population of the greater city, PS: population of the smaller city, D: distance

\section{References}

[1] Al Gar Allah, A. (1996). Analysis of the Saudi urban system by applying the traditional and modified version of the base of rank and size, Arabic journal of human sciences no. 55, 14th year, Kuwait university.

[2] Xiulian Ma. (1980), world Cities and National Urban System in China Part 3 : System Analysis and Risk, chapter 2 : urban system.

[3] El -Zamely, H. (1994), The Impact of Aridity on the Egyption Arid Settlements System, P.H.D, Cairo University.

[4] ZHANG Jing-Xiang1, Wu Qi-Yan2, Rui Fu-Hong (2001), (1-Department of urban and Resources science, Nanjing University, Nanjiang 210093, P.R. China; 2-Department of Architecture, Yunnan Polytechinc University, Kunming 650051, P.R. China), Chinese Geographical Science, Volume 11, Number 2, PP.129-136, Science press Beijing, China.

[5] P.Masure \& C.Lutoff (2006). Part 3 :System Analysis and Risk, Chapter 2: Urban System Exposure to Natural Disaster: an Integrated Approach, Bureau De Recherches Geologiques et Minieres, Chambery, France.

[6] Shipman Martin, Br., In Association with NUI Maynooth Fitzpatrick Associates (2000). The Irish Urban System and Its Dynamics.

[7] Williams, J., (1983). Cities of The World, World Regional and Urban Development, Harpperand Edit.
[8] Abdul Maksoud, Fa. (2003). Future Trends of the Urban System, ISO Carp Congress.

[9] Osman, Asma Ahmed (2014). Urban system analysis of Northern Upper Egypt, unpublished master's thesis, department of architecture, faculty of engineering, university of Minya.

[10] Nour Eddine, Abdulhaleem (2001). Egyptian archaeological sites and museums, Cairo.

[11] Abou Korin, Antar (2014). Analysis of the urban system in the Nile valley, Egypt, vol. 42, no. 2, journal of engineering sciences, faculty of engineering, Assiut university.

[12] Osman, A. Ahmed, Antar A. Abu korin, Ashraf M. Soliman \& Amani N. Abd Elhafez (2015). size distribution analysis of urban settlemet North level "Minia Journal of Engineering and Technology (MJET), Vol. 34. No1.January, university of Minya.

[13] Ministry of housing, utilities and physical development, general authority for physical planning, department of regional planning (2004). Northern region comprehensive development strategy first report: trends in the overall development of the region.

[14] El Bawab, M. Fouad (2004). Spatial distribution of urban settlements Egyptian urban system analysis, unpublished $\mathrm{PhD}$, department of architecture, faculty of engineering, Cairo University.

[15] Al-Jabry, N. Yaqzan (2005). Analysis of the urban system in the Makkah al-Mukarramah administrative region, unpublished $\mathrm{PhD}$ thesis, geography department, umm Al-Qurah University, Makkah al-Mukarramah, Saudi Arabia. [16] Christaller, W., (1966). Central Places in Southern Germany, Translated by C.W. Bsskin, Prentice- Hall, Englewood Cliffs, New Jersey.

[17] Ismail, A. Ali (2001). Studies in city geography, fourth edition, Cairo house of culture, publishing and distribution.

[18] Ahmed, A. Ahmed (2000). Urban method for determining the role of urbanization in promoting balanced development, unpublished master's thesis, school of regional and urban planning, department of regional development, Cairo university.

[19] Al-Muslimy, I. Al-Sayed Ahmed (1990). Urban sprawl of the secondary cities and the influence of regional and social factors on its characteristics between 1976-1989, unpublished master's thesis, department of architecture, faculty of engineering, Cairo University.

[20] Zipf, G. K., (1949). Human Behaviour and the Principle of least Effort Cambridge, Addison- Wesley Press.

[21] Jefferson, M., (1939). The Law of the primate city, Geographical Review. 29, pp. 226-36.

[22] Abdel-El All, A. Mohammed (1997). Regional differences in the level of development in Egypt, journal of geography and development, service centre for research and consultancy, no. 9, Minafweh University.

[23] El-Saleh, N. Abdullah and Mohammad Mahmud Al-Syriany (2000). Quantitative and statistical geography, fundamentals and applications by modern computer methods, first edition, Saudi Arabia: Abikan publishing.

[24] CAPMAS. Statistical Yearbook (2006). General population censuses and housing and housing conditions in Egypt.

[25] CAPMAS. Statistical Yearbook, general population censuses 1976, 1986, 1996", 2006, 2016 